\title{
THE USE OF PICTURE AND PICTURE TECHNIQUE IN IMPROVING STUDENT WRITING SKILL
}

\author{
Nurhajah Tia Sarifah ${ }^{1}$, Yanuarti Apsari ${ }^{2}$ \\ ${ }^{1}$ IKIP Siliwangi \\ ${ }^{2}$ IKIP Siliwangi \\ ${ }^{1}$ sarifahtia97@student.ikipsiliwangi.ac.id, ${ }^{2}$ yanuar.apsari1@gmail.com
}

\begin{abstract}
This study is aimed to know whether picture and picture technique can improve students' writing skill. The method used was quantitative research with one group pre-test and post-test research design. The population was the $11^{\text {th }}$ grade students at SMK Tunas Bangsa. The sample was one class of mechanical engineering major and consisted of 35 students.The result showed that null hypothesis of this study was rejected. It is proved by the data from T-test that shows the Sig. 2 tailed is 0.000 . This value is less than 0.05. Null hypothesis, therefore, was rejected. This means that picture and picture could improve students' writing skill.
\end{abstract}

Keywords: Picture And Picture, Writing, Descriptive Text

\section{INTRODUCTION}

Writing is the one of the four language skills that can be a measurement of literacy development in a country. Writing skill is regarded as the most difficult and complex language skill, because it requires extent of perception and involves thinking process extensively to produce idea, words, sentences, paragraphs, and the word composition. Tarigan (2013) cited in Lazulfa (2019) states the definition of writing as a skill of language. He explains writing is one of language skill, which is used to communicate directly, without having face to face with other people. Graham (2006) as cited in Parmawati, Santoso, Yana (2020) states that students have to struggle significantly with writing and if someone does not write well he will find difficulties in the process of learning, education, andwork. So, it can be concluded that writing is a complex process which is neither easy nor spontaneous for many second language learners.

There is no doubt that among four skills, writing is a difficult skill for second language or foreign language learners to be mastered. This is same with situation on the place of the research, the data showed that there are several problems dealing with students' writing skill at SMK Tunas Bangsa, especially at eleventh grade of mechanical engineering. This can be seen from the students' score in writing descriptive text. Most of them had low score in pre-test. The teacher can use an attractive method or technique in teaching writing descriptive text. One of attractive that is rare to be used picture and picture technique. This technique uses pictures as a stimulus for language experience activities in the classroom (Calhoun, 2009 in Meliasari \& Marmanto 2018).This technique is developed specifically for teaching students to read and write. The benefit from this technique is that it can improving students' interest and make writing activity more interesting. The use of picture also enchance the students' participation and interaction during the learning activities Sa'diyah in (Sesrica et al., 2017). It can also improve students' quality of writing and vocabulary (Apsari, 2017). 
Several studies have been conducted in the are of teaching writing descriptive text by using picture and picture. Most of students were conducting in secondary school and discovered the effectiveness of picture and picture in improving writing skill. There is never had before, the study that which investigate the use of picture and picture technique in teaching writing descriptive text. Therefore, this study aims to fill this gap by implementing picture and picture at SMK Tunas Bangsa. The null hypothesis of this study is picture and picture is not effective in improving students' writing skill.

\section{Writing}

According to Harmer (2004) in Putri \& Adnan (2019) writing is the way to express ideas in written form using letters, words, art or media. Text are whole pieces of writing which hang together as a complete product. Meanwhile, Byrne (1988) in Novariana et al., (2018) states that writing refers to process of instruction. As stated by Brown (2006) says that writing skills rerquire five general aspect: content, organization, vocabulary, grammar, and mechanics (Harmer, 2004 in Novianda, 2017) the teacher can use the strategies: planning, drafting, and responding.

\section{Picture and Picture Technique}

Picture is the one of learning media that can make students enjoy all the part of learning process. Because picture is the one way to explain the real situation also can bring the outside world into the classroom in a concrete way with clearly. Wright (1989) in Apsari (2017) says that pictures can be use by teachers and students whatever the emphasis of the syllabus they are following. Pictures have several functions in teaching and learning process. First, pictures can translate abstract ideas into more realistic forms. Second, picture is easily to be obtained. Third, picture can save the teachers' time and energy. There are some procedures in using picture and picture: jumble sentence, relevant sentence, change some words, picture guide story. According to Huda (2014) in Barr (2015) picture and picture is a learning technique and the part of cooperative learning that uses pictures as a lerning media, to apply picture and picture technique there are several steps that must be followed that is submissions, present the material, picture presentation, picture framing.

\section{METHOD}

This study was quantitative with one with one group pre-test and post-test research design. The population was 8th grade students at Tunas Bangsa. This study only took one class at mechanical engineering and consisted of 35 students. This class was selected as during the intership program conducted by the researcher. The students had low score in writing and learning English. The investigated class was then given a treatment, picture and picture. The treatment was conducted 3 times, from October $15^{\text {th }} 2019$ to October $29^{\text {th }} 2019$.

To collect the data needed, this study used picture and picture that improving writing descriptive text. The test was given two times, before and after treatment. The objectives was to know the improving students score in writing descriptive text (Muijs, 2010). The result of the test was then classiefied into the following table:

Table 1.1 Category of Writing by Brown (2006)

\begin{tabular}{lcccc}
\hline & \multicolumn{4}{c}{ Internal Score } \\
\hline Scoring Elements & Conten t & organization & $\begin{array}{c}\text { Vocabula } \\
\text { ry }\end{array}$ & Grammar \\
\hline
\end{tabular}




\begin{tabular}{ccccccc}
\hline Writing & Less & $16-13$ & $9-7$ & $9-7$ & $10-5$ & 2 \\
\cline { 2 - 7 } Categorize & Low & $21-17$ & $13-10$ & $13-10$ & $17-11$ & 3 \\
\cline { 2 - 7 } & Enough & $26-22$ & $17-14$ & $17-14$ & $21-18$ & 4 \\
\cline { 2 - 7 } & Good & $30-27$ & $20-18$ & $20-18$ & $25-22$ & 5 \\
\hline
\end{tabular}

The collected data was then analyzed by using SPSS version 25 . In analyzing the data, the mean and standard deviation of students' test was counted. Besides, the normality of the data was also tested. The T-test was the used to investigate the difference of students' score before and after giving the treatment.

\section{RESULTS AND DISCUSSION}

\section{Results}

1. Students' Pretest and Posttest

This study used essay test in writing descriptive text which was given before and after the treatment. The result can be seen in the following table:

Table 1.2 The result of students' pretest and posttest

\begin{tabular}{c|c|c|c|c|c|c|c} 
No & Name & Pri-test & Post-test & \multicolumn{1}{c}{ No } & \multicolumn{1}{c}{ Name } & Pr-test & Post-test \\
\hline 1 & Student-1 & 43 & 75 & 19 & Student-19 & 52 & 75 \\
\hline 2 & Student-2 & 57 & 75 & 20 & Student-20 & 49 & 77 \\
\hline 3 & Student-3 & 52 & 75 & 21 & Student-21 & 53 & 74 \\
\hline 4 & Student-4 & 46 & 74 & 22 & Student-22 & 47 & 75 \\
\hline 5 & Student-5 & 52 & 78 & 23 & Student-23 & 51 & 78 \\
\hline 6 & Student-6 & 58 & 63 & 24 & Student-24 & 44 & 74 \\
\hline 7 & Student-7 & 54 & 65 & 25 & Student-25 & 50 & 73 \\
\hline 8 & Student-8 & 55 & 75 & 26 & Student-26 & 50 & 70 \\
\hline 9 & Student-9 & 57 & 81 & 27 & Student-27 & 47 & 72 \\
\hline 10 & Student-10 & 46 & 77 & 28 & Student-28 & 52 & 73 \\
\hline 11 & Student-11 & 40 & 77 & 29 & Student-29 & 52 & 74 \\
\hline 12 & Student-12 & 44 & 73 & 30 & Student-30 & 42 & 73 \\
\hline 13 & Student-13 & 49 & 69 & 31 & Student-31 & 44 & 65 \\
\hline 14 & Student-14 & 40 & 74 & 32 & Student-32 & 44 & 75 \\
\hline 15 & Student-15 & 47 & 69 & 33 & Student-33 & 47 & 75 \\
\hline 16 & Student-16 & 52 & 76 & 34 & Student-34 & 50 & 75 \\
\hline 17 & Student-17 & 56 & 72 & 35 & Student-35 & 59 & 80 \\
\hline 18 & Student-18 & 54 & 75 & & & &
\end{tabular}

From the above table it can be seen that the lowest score in pre-test was 40, while the highest score was 59. On the other hand, in posttest the lowest score in post-test was 63 , while the highest score 81 . This indicates that the students' writing descriptive text after giving the treatment improved rather than before giving the treatment. Meanwhile the mean score and the standard deviation of pre-test and post-test is provided in the table below:

Table 1.3 total mean score standard deviation of the students in pre-test and post-test score

\begin{tabular}{ccccc}
\hline \multirow{2}{*}{$\begin{array}{c}\text { Class } \\
\text { Experimental }\end{array}$} & \multicolumn{2}{c}{ Pre-test } & \multicolumn{2}{c}{ Post-test } \\
\cline { 2 - 5 } & Mean score & $\begin{array}{c}\text { Standard } \\
\text { deviation }\end{array}$ & Mean score & $\begin{array}{c}\text { Standard } \\
\text { deviation }\end{array}$ \\
\cline { 2 - 5 } & 49.57 & 5.118 & 73.86 & 3.994 \\
\hline
\end{tabular}


The result of table above shows that the mean score of students' pre-test was 49.57 , while post-test was 73.86. Meantime, the standard deviation of pre-test was 5.118, while post-test was 3.994. This score, again, indicates that the students' post-test was better than the students' pre-test score. In other words, picture and picture technique was able to improving students' writing skill in descriptive text.

\section{Normality}

The normality test was conducted to know whether the data distribution was normal or not. If the normality is more than the level of significance $\alpha(0.05)$, the data is normality distributed (Sulistya et al., 2019). The result of normality test can be seen below:

\begin{tabular}{lllllll}
\hline \multicolumn{7}{c}{ Table 1.4 Tests of Normality } \\
\hline & Kolmogorov-Smirnov & \multicolumn{5}{c}{ Shapiro-Wilk } \\
\cline { 2 - 7 } & Statistic & Df & Sig. & Statistic & Df & Sig. \\
\hline Pre-test &, 111 & 35 &, $200^{*}$ &, 972 & 35 &, 511 \\
\hline $\begin{array}{l}\text { Post- } \\
\text { test }\end{array}$ &, 186 & 35 &, 003 &, 914 & 35 &, 010 \\
\end{tabular}

Base on the result above, the value of Sig. present was 0.511 and posttest was 0.010 . It showed that the value was more than the level of significance. It, therefore, can be concluded that the data of this present study has normally distributed.

\section{Homogeneity}

The homogeneity test was conducted to know whether the variance oin the two samples has the same varience or not (Setiawan \& Qomariyah, 2016). The result of homogeneity test can be seen below:

\begin{tabular}{lccc}
\hline \multicolumn{4}{l}{ Table 1.5 Test of Homogeneity of Variances } \\
\hline score & & & \\
\hline $\begin{array}{l}\text { Levene } \\
\text { Statistic }\end{array}$ & $\mathrm{df1}$ & $\mathrm{df2}$ & Sig. \\
\hline 4,556 & 1 & 68 &, 036 \\
\hline
\end{tabular}

From the result of homogeinity test above, it could be seen that the significance of the data from pre-test and post-test score was 0.036. It means the significance of the data is lowest

Independent Samples Test

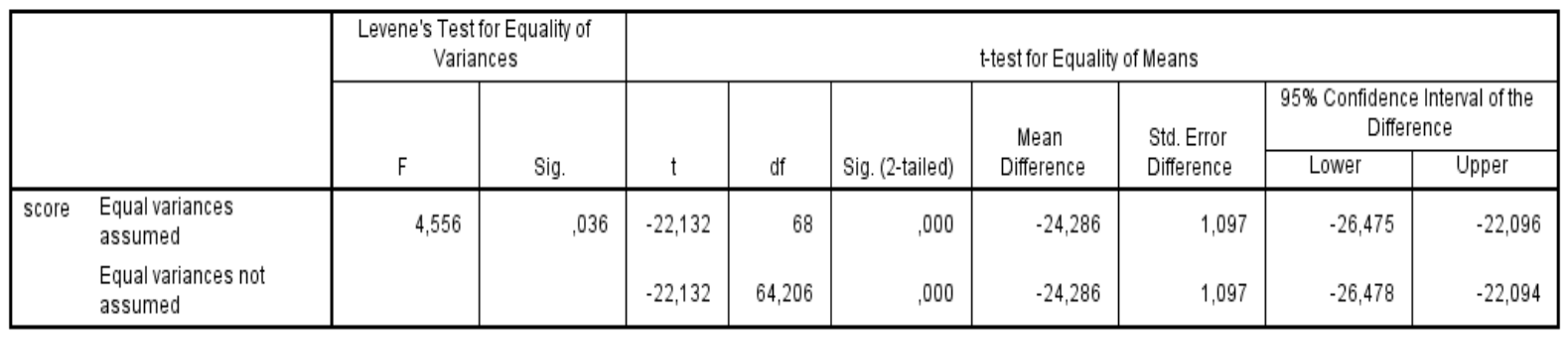

than the significance degree $(\alpha=0.05)$. the result of homogeinity test shows that pre-test and post-test score was not homogen so that it can be tested by using T-test'.

4. T-test'

The T-test' is also called the hypothesis test. The test was conducted to test whether the hypothesis proposed is accepted or not. According to Sugiyono (2009) in Muzaki et al.,, (2020) that t-test is one of the statistical test used to test the truth or falsehood of the null hypothesis which states that two sample mean is no significance difference. The result of $t-$ test can be seen below: 


\section{Table 1.6 Test of T-test}

The table showed that Sig-2 tailed was 0.000 , this was lower than 0.05 . This means that $\mathrm{H}_{0}$ of this study was rejected. In the other words. The use of picture and picture is effective in improving students' writing skill.

\section{CONCLUSION}

Based on the result of this study, picture and picture technique in improving students' writing skill. It is proved by the data from t-test that shows the sig. 2 tailed is 0.000 . This value is low than 0.05. Null hypothesis, therefore, is rejected. Based on the result of this study, it is suggested for the teacher who have students' with low improving in learning writing descriptive text to use picture and picture in the learning and teaching process. This study shows that picture and picture can make students improving their writing skill in descriptive text.

\section{ACKNOWLEDGMENTS}

Alhamdulillah all gratitude to Allah S.W.T who gave His blessing to researcher, so researchers can finish this article without any problem. Researcher would like to say bigest thank you for all people that has been give a big support when researcher conducting this research, and for the risearcher article supervisor how always gave her times to guiding in this pandemic situation. Also for IKIP Siliwangi, researcher would like to say thank you that which gave the opportunity to publish this article.

\section{REFERENCES}

Apsari, Y. (2017). The use of picture series in teaching writing recount text. ELTIN Journal, 5(II), 51-56.

Barr, F. D. (2015). Problematika penerapan model pembelajaran kooperatif tipe teams games tournaments ( tgt ) dan alternatif penyelesaiannya pada pembelajaran program studi pendidikan matematika program pascasarjana 2015.

Brown, H. D. (2006). Principles of language learning and teaching (xi). Pearson Education.

Lazulfa, I. (2019). Keterampilan berbahasa menulis teks eksposisi.

Meliasari, R., \& Marmanto, S. (2018). Picture Word Inductive Model: Its Effectiveness to Teach Writing V iewed from Students 'Interest. 2(3), 248-258.

Muijs, D. (2010). Doing quantitative research in education.

Muzaki, R., Maliki, O., \& Kusuma, B. (2020). Journal of Sport Coaching and Physical Education Latihan Sirkuit Terhadap Kecepatan Kelincahan dan Daya Tahan pada UKM Futsal Putra Abstrak. 5(1), 48-54.

Novariana, H., Sumardi, \& Tarjana, S. S. (2018). Senior High School Students' Problems in Writing A Preliminary Study of Implementing Writing E-Journal as Self Assessment to Promote Students' Writing Skill. English Language and Literature International Conference (ELLiC), 2(November), 216-219. jurnal.unimus.ac.id

Novianda, R. (2017). Teaching speaking by using picture strip stories. English Education Journal (EEJ), 8((3)), 386-403.

Parmawati, A., Santoso, I., \& Yana, Y. (2020). Improving Students'writing Skill Through Round Table Technique. ELTIN JOURNAL, Journal of English Language Teaching in Indonesia, 8(2), 103-111.

Putri, I., \& Adnan, A. (2019). Journal of English Language Teaching teaching spoken narrative text by using animation. 8(1).

Sesrica, M., Jismulatif, \& Afrianto. (2017). The effect of using pictures in teaching writing 
descriptive text for the second year students of smpn 1 siak hulu menulis deskriptif teks siswa tahun kedua smpn 1 siak hulu. 1-8.

Setiawan, R., \& Qomariyah, N. I. (2016). Implementation analysis of character-basededucation policy on. Jurnal pendidikan biologi indonesia, 2(2), 147-153.

Sulistya, B. R., Atmaja, H. T., \& Setyowati, D. L. (2019). The Effectiveness of The Thematic Instructional Materials in Improving Social Sciences Basic Competence by Using Problem-Based Learning Model in Elementary School Article Info. Journal of Primary Education, 8(1), 10-15. https://doi.org/10.15294/jpe.v8i1.24624 